\title{
The Foraging Tactics of Chestnut-winged Babbler (Stachyris erythroptera) and Abbott's Babbler (Malacocincla abbotti) in a Lowland Rainforest, Malaysia (Corak Pencarian Makanan oleh Rimba Merbah Sampah (Stachyris erythroptera) dan Rimba Riang (Malacocincla abbotti) di Hutan Hujan Tanah Rendah, Malaysia)
}

\author{
MOHAMMAD SAIFUl MANSOR*, Rosli RAMLI \& SHAHRUL ANUAR MOHD SAH
}

\begin{abstract}
Foraging pattern of Chestnut-winged Babbler (Stachyris erythroptera) and Abbott's Babbler (Malacocincla abbotti) was studied in Lenggong Valley, Perak from July 2010 until July 2011. The study examines the patterns of foraging height, foraging substrates and attack manoeuvres of two babbler species (Family: Timaliidae), to explain how these trophically similar species can coexist in the same habitat; a central question in ecology. Information on the foraging height, foraging substrate and attack manoeuvres was collected independently for each foraging bird. Principal component analysis and Pearson's correlation analysis showed that these two species used similar proportion of foraging height (>0-2 $\mathrm{m}$ above the ground) and foraging substrate (dead leaves), but differed in the use of attack manoeuvres. The Chestnut-winged babbler used primarily stretching manoeuvre, whereas the Abbott's babbler used primarily gleaning manoeuvre. This niche separation allowed these species to coexist in the same area, thus follows the Gause' Law of competitive exclusion, that states two species occupying the same niches will not coexist forever.
\end{abstract}

Keywords: Behaviour; foraging ecology; insectivorous birds; niche separation, tropical forest

\section{ABSTRAK}

Corak pencarian makanan oleh Rimba Merbah Sampah (Stachyris erythroptera) dan Rimba Riang (Malacocincla abbotti) telah dikaji di Lembah Lenggong, Perak dari Julai 2010 hingga Julai 2011. Kajian ini menilai corak penggunaan tahap ketinggian, jenis substrat dan cara pergerakan serangan semasa mencari makanan oleh dua spesies babbler (Famili: Timaliidae), untuk mengkaji bagaimana spesies yang mempunyai persamaan diet boleh wujud dalam habitat yang sama; persoalan pusat dalam ekologi. Maklumat tentang penggunaan tahap ketinggian, jenis substrat dan cara pergerakan serangan semasa mencari makanan diambil secara bebas untuk setiap burung pemburuan. Analisis prinsip komponen dan analisis korelasi Pearson menunjukkan spesies ini menggunakan ketinggian ( $>0-2 \mathrm{~m}$ dari atas tanah) dan jenis substrat (daun-daun mati) yang sama, tetapi menggunakan cara serangan yang berbeza semasa mencari makanan. Rimba Merbah Sampah lazimnya menggunakan cara pergerakan meregang manakala Rimba Riang lazimnya menggunakan cara pergerakan memungut. Pemisahan nic membenarkan dua spesies burung ini untuk tinggal bersama di kawasan yang sama, menepati Undang-undang Gause pengecualian kompetitif yang menyatakan dua spesies yang memiliki pengkhususan yang sama tidak akan wujud bersama-sama selama-lamanya.

Kata kunci: Burung pemakan serangga; ekologi pencarian makanan; hutan tropika; nic pemisahan; tingkah laku

\section{INTRODUCTION}

Lenggong Valley consists of eight limestone hills with a dense lowland tropical forest. Lowland tropical rainforest supports a great proportion of bird species in the Southeast Asia (Sodhi et al. 2010; Wells 2007). Over 260 of the 638 bird species recorded from both Peninsular Malaysia and Singapore are inhabitants in lowland forest and their population may extend into lower montane forest (Strange \& Jeyarajasingam 1999). A great number of ecological niches provided by complex terrains (e.g. fissured cliffs and extensive caves) and variable climatic conditions in limestone area also support bird diversity (Clements et al. 2006).

Tropical birds are highly diverse and their ecological niches are quite varied and reasonably well-known. Birds are good bio-indicators in the study of the impacts of forest disturbance (Karr et al. 1990). Studies on foraging ecology of birds provide an understanding of the ways in which ecologically different species partition their resources in a habitat and may reveal how guilds of forest birds respond to disturbance (Styring \& Zakaria 2004). Resource partitioning reduces the competition rates by decreasing the amount of niche overlaps between the competitor species (Wiens 1989).

The foraging ecology of trophically similar species has been intensively studied since the beginning of 1960 s (Sturman 1968). However, the knowledge on the foraging ecology of tropical birds is sufficient, particularly in the Southeast Asia. The foraging strategies of birds may be affected by habitat structure (Maurer \& Whitemore 1981). 
The objectives of this study were to describe the foraging strategies and to determine the attack manoeuvres and substrates used by two related species (Family: Timaliidae), Chestnut-winged Babbler (Stachyris erythroptera) and Abbott's Babbler (Malacocincla abbotti), in order to understand how these trophically similar species can coexist in the same habitat. Resource segregation can occur in related species by differential selection of foraging height, substrate and attack manoeuvres (Weimerskirch et al. 2009). This niche partitioning allows them to coexist in the same geographical area (Kwok 2009).

\section{MATERIALS AND METHODS}

\section{STUDY AREA}

The field work was conducted at the Bukit Kepala Gajah limestone area in Lenggong Valley, Perak from July 2010 to July 2011 (Figure 1). The Lenggong Valley is an important archaeological site. Evidence of human settlement from the Palaeolithic Age has been found in the valley (Majid 1994). Bukit Kepala Gajah, one of eight limestone hills in the Lenggong Valley of Ulu Perak, is located approximately $150 \mathrm{~m}$ above sea level and approximately $3 \mathrm{~km}$ in the north of Lenggong town. The area is located between $5^{\circ}$
7.474' $\mathrm{N} 100^{\circ} 58.751^{\prime} \mathrm{E}$ and $5^{\circ} 7.957^{\prime} \mathrm{N} 100^{\circ} 58.432^{\prime} \mathrm{E}$ The vegetation is generally mixed (lowland dipterocarp forest, limestone forest, orchards and secondary forest) with temperature $30-33^{\circ} \mathrm{C}$ and high relative humidity of 80-90\% (Chia \& Majid 2002).

\section{FORAGING OBSERVATION}

Birds were observed visually and randomly along a forest trail and followed opportunistically. Observations were done between 0730 and $1830 \mathrm{~h}$. Observations on each foraging bird were made using $8 \times 42$ binoculars (Omicron - Estavia), recorded on voice recorder (Olympus - VN5500PC) and later transcribed to data spreedsheets. Birds were observed as long as they could be kept in view, but only the initial (independent) observations, first sighting of an individual bird, were used for statistical analysis to avoid problems with non-independent data (Styring \& Zakaria 2004). At least 30 independent observations were taken for each bird species to represent the observed behaviour accurately (MacNally 1994; Morrison 1984; Somasundaram \& Vijayan 2008). Observations were not made on mixed-species flocks because membership in a mixed-species flock also affects the independence of foraging behaviour of birds (Sridhar et al. 2009).
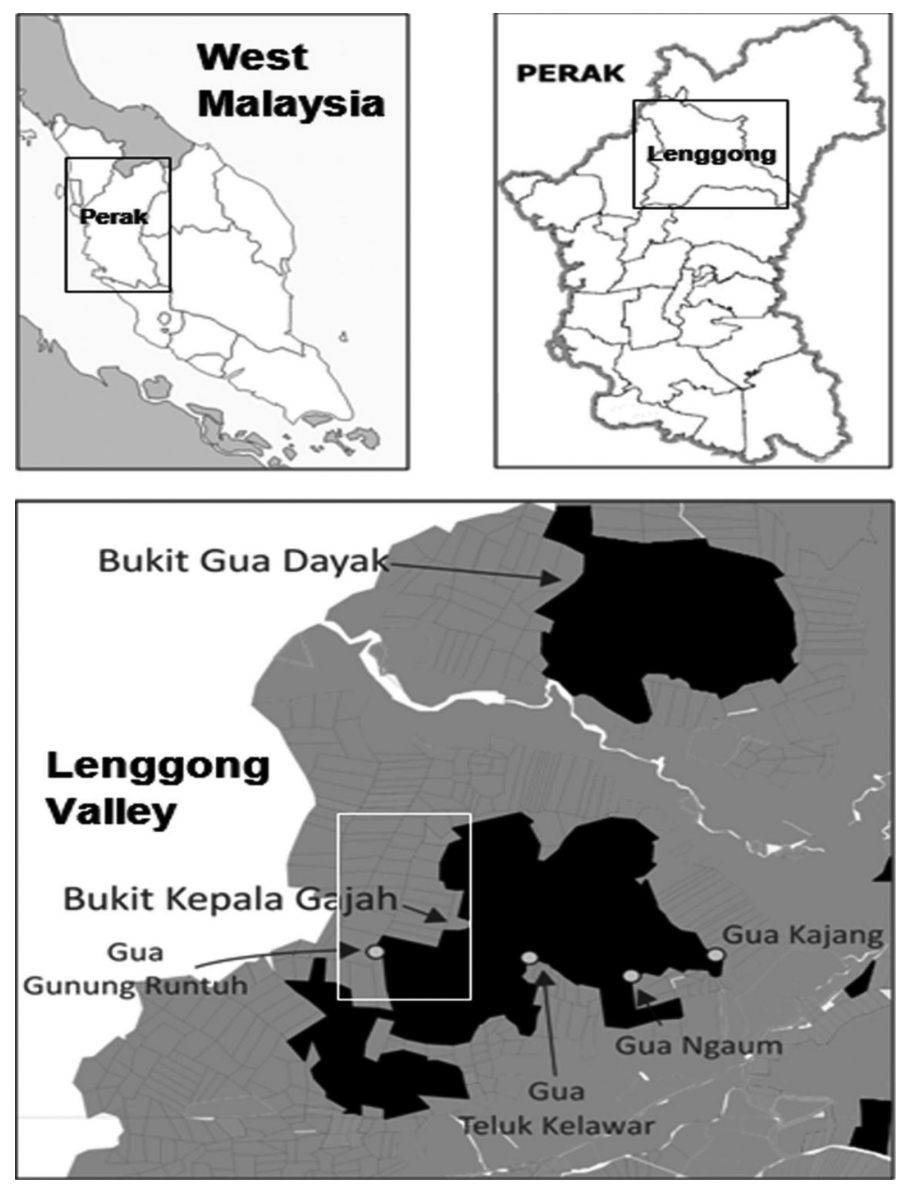

FIGURE 1. Location of Lenggong Valley, Perak and the study site Bukit Kepala Gajah area 
The following data were recorded on each foraging bird encountered opportunistically: estimated height above the ground (foraging height); foraging substrate; and attack manoeuvres. Foraging parameters used are described below:

Foraging height A foraging height is the height level from which a food item is taken by the birds. Selected trees were height-marked for use as reference for standardization, following Somasundaram and Vijayan (2008).

Foraging substrate A foraging substrate (leaves, branches, twigs, dead tree parts and litter) is the material (microhabitat) from which a food item is taken by the birds.

Attack manoeuvre The attack manoeuvres (glean, stretch, hang, probe and sally) is a method on how the food items taken (attack) by the birds (Table 1). The terminology and strategy used to characterize attack manoeuvres follows Remsen and Robinson (1990).

\section{STATISTICAL ANALYSIS}

The Multivariate Statistical Package (MVSP 3.13; Kovach Computing Services, Wales) was used to perform principal component analysis (PCA) on raw foraging data set. PCA is a method that reduces data by forming linear combinations of variables and summarizes it into new synthetic variables (called principal components). The Pearson's correlation coefficient was used to examine niche overlap among the species studied. Recognising the overlap of bird species in their utilisation of space, food and other resources is important to study the species interactions and community structure (Hurlbert 1978; Krebs 1999).

\section{RESULTS}

A total of 130 independent observations were made on two focal species of babbler, 99 for the Chestnut-winged Babbler and 31 for the Abbott's Babbler, throughout the study period. These species are resident species and feed primarily on insects and other small invertebrates (Robson 2008; Wells 2007).

\section{FORAGING HEIGHT}

The study defined eight height categories: Ground, $>0-2$, $>2-4,>4-6,>6-8,>8-10,>10-12$ and $>12 \mathrm{~m}$ above the ground (Table 2). The birds used all of these strata except $>6-8$ and $>12 \mathrm{~m}$. Both babblers preferred foraging height of $>0-2 \mathrm{~m}$ ( $>80 \%$ in frequency). Chestnut-winged babbler occasionally used $>2-4 \mathrm{~m}$ (14.14\%), while Abbott's babbler tends to use ground level $(9.68 \%)$ and rarely $>2-4 \mathrm{~m}(3.23 \%)$.

\section{FORAGING SUBSTRATE}

A total of five substrates were identified in the study area. These substrates were the green leaves, branches, twigs, dead tree parts (hanging dead leaves and dead branches) and leaf litter. Both species mainly used the hanging dead leaves as foraging substrate and occasionally on green leaves. Abbott's babbler also tends to use branches, twigs and leaf litter, in low frequency $(6.45 \%)$.

\section{ATTACK MANOEUVRES}

Stretching (53.54\%) was the most frequently used manoeuvre by Chestnut-winged babbler, followed by gleaning (26.26\%), probing $(11.11 \%)$ and hanging (9.09\%). Abbott's babbler mainly used gleaning (70.97\%), followed by stretching $(22.58 \%)$ and rarely sallying manoeuvre $(6.45 \%)$.

\section{POTENTIAL NICHE OVERLAP}

Pearson's correlation analysis showed that these two babbler species used similar proportion of foraging height ( $>0-2 \mathrm{~m}$ above the ground) and foraging substrate (hanging dead leaves). However, the use of attack manoeuvres differed significantly between them. The analyses also showed that the highest mean niche overlap among these species was found in the use of foraging substrate $(r=0.994, p=0.001)$, followed by foraging height $(r=0.982, p=0.000)$, and the smallest overlap was found in the use of attack manoeuvres $(r=0.427$, $p=0.474)$.

The two principal components of PCA accounted for 90 and $100 \%$ variation, respectively. The PCA plot showed the most frequently used attack manoeuvres by the focal species and foraging height that only used by the Abbott's Babbler (Figure 2). The Chestnut-winged Babbler used primarily stretching manoeuvre and never foraged on

TABLE 1. Description of attack manoeuvres used in this study (Remsen \& Robinson 1990)

\begin{tabular}{ll}
\hline Attack manoeuvre & Descriptions \\
\hline Glean & To pick food from a nearby substrate. Can be reached without full extension of legs or neck \\
Stretch & To completely extend the legs or neck to reach the food items \\
Hang & To hang head down in order to reach food not obtainable by any other perched position \\
Probe & To insert the bill into softer substrate such as dead leaves to capture hidden food \\
Sally & To fly from a perch to attack a food item and then return to a perch \\
\hline
\end{tabular}


TABLE 2. Foraging height, foraging substrate and attack manoeuvre variables.

$\mathrm{N}$ - sample size, data are given as percentages (\%)

\begin{tabular}{llccc}
\hline \multirow{2}{*}{ Foraging parameters } & & \multicolumn{2}{c}{ Species } & \\
& & Chestnut-winged Babbler & Abbott's Babbler \\
\hline Foraging height & Ground & 0 & 9.68 \\
& $>0-2$ & 81.82 & 87.1 \\
& $>2-4$ & 14.14 & 3.23 \\
& $>4-6$ & 2.02 & 0 \\
& $>6-8$ & 0 & 0 \\
& $>8-10$ & 1.01 & 0 \\
& $>10-12$ & 1.01 & 0 \\
Foraging substrate & 0 & 0 \\
& $>12$ & 17.17 & 22.58 \\
& Green leaves & 0 & 6.45 \\
& Branches & 0 & 6.45 \\
& Twigs & 82.83 & 58.06 \\
& Dead leaves & 0 & 6.45 \\
& Leaf litter & 26.26 & 70.97 \\
& Gleaning & 53.54 & 22.58 \\
& Stretching & 9.09 & 0 \\
& Hanging & 11.11 & 0 \\
& Probing & 0 & 6.45 \\
& Sallying & 99 & 31 \\
\hline
\end{tabular}

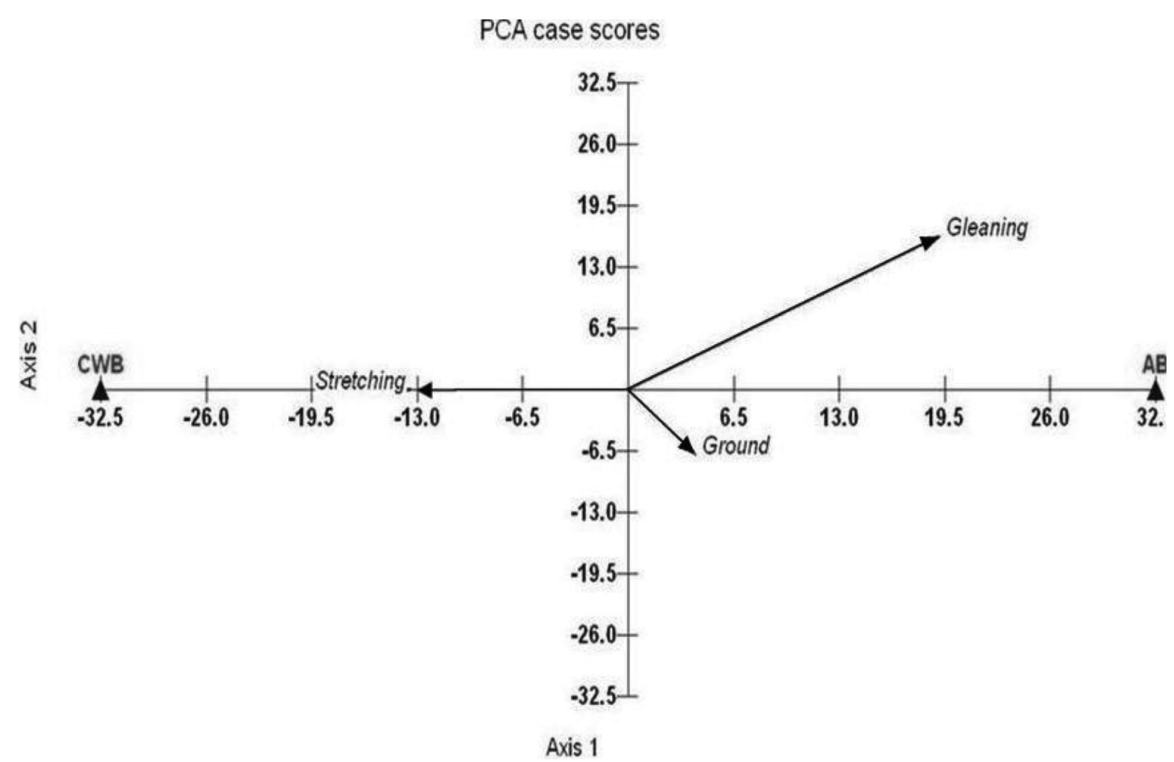

FIGURE 2. Component plots of foraging variables (foraging height, foraging substrate, attack manoeuvres)

the ground level, whereas the Abbott's babbler used primarily gleaning manoeuvre and foraged occasionally on the ground level.

\section{DISCUSSION}

The study showed that the focal species observed at the study site exhibited a great range of foraging strategies. The highest mean niche overlapping between these species was recorded in the use of foraging substrate and foraging height. Both babbler species foraged frequently on the dead leaves. Curled dead leaves supported high insect density (Gradwohl \& Greenberg 1982) and also served as daytime hiding places for nocturnal arthropods (Remsen \& Parker 1984), thus attracting more birds to forage. Hanging dead leaves were found abundant in the understory of tropical forest (Rosenberg 1997), this explain the reason that the focal species preferred to forage on shrub level $(>0-2 \mathrm{~m})$. In addition, the pattern of foraging height used by both species reflects the availability of food resources, the morphology 
of the birds and interspecific competition with other bird species (Loyn 2002).

However, the use of attack manoeuvres differed significantly among them. This niche partition allowed these birds to coexist in the same area by reducing the competition among them (Ishtiaq et al. 2010; Kwok 2009; Pianka 1974). The Chestnut-winged Babbler specialised in more acrobatic posture (stretching or reaching) than gleaning manoeuvre that was preferred by the Abbott's Babbler. The capability of Chestnut-winged Babbler to extend the legs or neck upwards, outwards, or downwards to reach food item allowed them to be more successful to forage in a flock than gleaning birds (Remsen \& Robinson 1990), thus contributing in their numbers. Certain species like Abbott's Babbler tend to adopted gleaning manoeuvre as they were generally solitary forager. Thus, they may not use much energy to forage as the gleaning is presumably the least energy expenditure manoeuvre (Remsen \& Robinson 1990). Birds show special morphological adaptations that correspond to specialized attack manoeuvres used to forage on particular substrates. Bird morphology may thus limit the usage of attack manoeuvres (Rolando \& Robotti 1985).

\section{CONCLUSION}

The study showed that the focal species exhibited a great range of foraging strategies. The degree of niche overlap among these species was similar with respect to foraging height and substrate, but different in attack manoeuvres. This follows the Gause' Law of competitive exclusion that states two species that share the same niches cannot stably coexist (Hardin 1960). It is very important to understand the foraging preferences of so many trophically similar species in an area in order to understand how they can coexist in the same habitat, which is a central question in ecology.

\section{ACKNOWLEDGEMENTS}

We are grateful to Universiti Malaya Research Fund (PG019-2013B) and Universiti Sains Malaysia grant scheme (USM-RU and PRGS) that provided financial support for this wildlife survey. We also thank Yusof Omar, Nordin Ahmad, Rosnezam Mohamad, Syed Mohd Edzham, and lab mates for field assistance. We also thank Prof. Mohd Mohktar Saidin for accommodation, and $\mathrm{Kg}$. Gelok villagers. The study was conducted under approval from Animal Ethics Committee USM (AECUSM).

\section{REFERENCES}

Chia, S. \& Majid, Z. 2002. The conservation and preservation of Perak man from Gua Gunung Runtuh site in Lenggong, Perak, Malaysia. The International Symposium on the Conservation and Preservation of Java Man site (Indonesia) and Peking Man site (China). Solo, Indonesia. 15-20 April.

Clements, R., Sodhi, N.S., Schilthuizen, M. \& Ng, P.K.L. 2006. Limestone karsts of Southeast Asia: Imperiled arks of biodiversity. Bioscience 56: 733-742.
Gradwohl, J. \& Greenberg, R. 1982. The effect of a single species of avian predator on the arthropods of aerial leaf litter. Ecology 63: 581-583.

Hardin, G. 1960. The competitive exclusion principle. Science 131: $1292-1298$.

Hurlbert, S.H. 1978. The measurement of niche overlap and some relatives. Ecology 59(1): 67-77.

Ishtiaq, F., Javed, S., Coulter, M.C. \& Rahmani, A.R. 2010. Resource partitioning in three sympatric species of storks in Keoladeo National Park, India. Waterbirds 33(1): 41-49.

Karr, J.R., Robinson, S., Blake, J.G. \& Bierregaard, Jr. R.O. 1990. Birds of four neotropical forests. In Four Neotropical Rainforests, edited by Gentry, A.H. New Haven: Yale University Press.

Krebs, C.J. 1999. Ecological Methodology. 2nd ed. California: Addison Wesley Longman Inc.

Kwok, H.K. 2009. Foraging ecology of insectivorous birds in a mixed forest of Hong Kong. Acta Ecologica Sinica 29(6): 341-346.

Loyn, R.H. 2002. Patterns of ecological segregation among forest and woodland birds in south-eastern Australia. Ornithological Science 1: 7-27.

MacNally, R.M. 1994. Habitat-specific guild structure of forest birds in south-eastern Australia: A regional scale perspective. Journal of Animal Ecology 63(4): 988-1001.

Majid,Z. 1994. The excavation of Perak Man, an epi-palaeolithic burial at Gua Gunung Runtuh. In The Excavation of Gua Gunung Runtuh and the Discovery of the Perak Man in Malaysia, edited by Majid, Z. Kuala Lumpur: Department of Museums and Antiquity Malaysia Publishers.

Maurer, B.A. \& Whitmore, R.C. 1981 . Foraging behaviour of five bird species in two forests with different vegetation structure. The Wilson Bulletin 93: 478-490.

Morrison, M.L. 1984. Influence of sample size and sampling design on analysis of avian foraging behaviour. Condor 86(2): 146-150.

Pianka, E.R. 1974. Niche overlap and diffuse competition. Proceedings of the National Academy of Sciences of the United States of America 71(5): 2141-2145.

Remsen, J.V. \& Robinson, S.K. 1990. A classification scheme for foraging behaviour of birds in terrestrial habitats. Studies in Avian Biology 13: 144-160.

Remsen, J.V. \& Parker, T.A. 1984. Arboreal dead-leaf-searching birds of the Neotropics. Condor 86: 36-41.

Robson, C. 2008. A Field Guide to the Birds of South-east Asia. London: New Holland Publisher.

Rolando, A. \& Robotti, C.A. 1985. Foraging niches of tits and associated species in north-western Italy. Bollettino di Zoologia 52: 281-297.

Rosenberg, K.V. 1997. Ecology of dead-leaf foraging specialists and their contribution to Amazonian bird diversity. Ornithological Monograph 48: 673-700.

Sodhi, N.S., Posa, M.R.C., Lee, T.M., Bickford, D., Koh, L.P. \& Brook, B.W. 2010. The state and conservation of Southeast Asian biodiversity. Biodiversity and Conservation 19: 317328.

Somasundaram, S. \& Vijayan, L. 2008. Foraging behaviour and guild structure of birds in the montane wet temperate forest of the Palni Hills, South India. Podoces 3: 79-91.

Sridhar, H., Beauchamp, G. \& Shanker, K. 2009. Why do birds participate in mixed-species foraging flocks? A large-scale synthesis. Animal Behaviour 78(2): 337-347. 
Strange, M. \& Jeyarajasingam,A. 1999. A Photographic Guide to the Birds of Peninsular Malaysia and Singapore. Singapore: Sun Tree Publishing.

Sturman, W.A. 1968. The foraging ecology of Parus atricapillus and $P$. rufescens in the breeding season, with comparisons with other species of Parus. Condor 70: 309-322.

Styring, A.R. \& Zakaria, M. 2004. Foraging ecology of woodpeckers in lowland Malaysian rain forests. Journal of Tropical Ecology 20: 487-494.

Weimerskirch, H., Shaffer, S.A., Tremblay, Y., Costa, D.P., Gadenne, H., Kato, A., Coudert, Y.R., Sato, K. \& Aurioles, D. 2009. Species-and sex-specific differences in foraging behaviour and foraging zones in blue-footed and brown boobies in the Gulf of California. Marine Ecology Progress Series 391: 267-278.

Wells, D.R. 2007. The Birds of the Thai-Malay Peninsula. Volume II: Passerines. London: Christopher Helm.

Wiens, J.A. 1989. Ecology of Bird Communities - Volumes 1 \& 2. Cambridge: Cambridge University Press.

Mohammad Saiful Mansor* \& Rosli Ramli Laboratory of Zoological and Ecological Networking Institute of Biological Sciences, Faculty of Science University of Malaya, 50603 Kuala Lumpur Malaysia
Mohammad Saiful Mansor*

School of Environmental and Natural Resource Sciences

Faculty of Science and Technology

43600 UKM Bangi, Selangor Darul Ehsan

Malaysia

Shahrul Anuar Mohd Sah

School of Biological Sciences

Universiti Sains Malaysia

11800 Pulau Pinang

Malaysia

*Corresponding author; email: msaifulmansor@gmail.com

Received: 26 August 2014

Accepted: 26 January 2015 